\title{
Litigation following UK Water Resources Act section 110 appeal
}

Murray Chapman BSC, CEng, FICE

Landowner, Trewern Hall, Trewern, UK (y477um@yahoo.co.uk)

The first ever appeal under section 110 of the UK Water Resources Act 1991 took place in 2009. The appeal was against a refusal by the Environment Agency to give consent to an application made under section 109 of the Act for the repair and the reinstatement of a flood embankment at Trewern Hall in the Severn valley. The agency was found to have acted unreasonably and unlawfully in determining the application, and there was a full award of costs against it. This paper describes the litigation that followed the appeal and the granting of unconditional planning consent by the local planning authority in 2010.

\section{Introduction}

In 2011, a paper was published (Chapman, 2011) which described the events leading up to the first ever appeal under section 110 of the UK Water Resources Act 1991 (1991) - hereafter referred to as the WRA - and the obtaining of unconditional planning consent for the works on the Trewern 'argae' - a flood defence embankment to protect the grade II*-listed Trewern Hall in the Severn valley - about $6 \mathrm{~km}$ north-east of Welshpool in Powys.

The appeal was against the refusal by the Environment Agency (EA) to give consent to an application made under section 109 of the WRA for the repair and the reinstatement of the Trewern embankment. Among other matters, it was determined from the appeal that the EA had acted not only unreasonably but also unlawfully in its determination of the section 109 WRA application (letter reference A-PAE-24-01-qA745901/1 from the head of the Climate Change and Water Division, Welsh Assembly government). There was a full award of costs against the EA of $£ 255000$ (letter reference A-PAE-24-01-qA745901/1).

Further litigation ensued following the successful appeal under section 110 of the WRA and the granting of unconditional planning consent by the local planning authority (LPA) on 24 August 2010 for the works on the Trewern embankment. The further litigation, the subject of this paper, comprised the following

- the judicial review of the unconditional planning consent given on 24 August 2010 by the LPA

v the determination in accordance with section 73 of the Land Drainage Act 1991 (1991) - hereafter referred to as the LDA on whether or not the works on the Trewern embankment were drainage works in connection with a main river

- an action in the Queen's Bench Division of the High Court of Justice for the negligence/breach of duty by two barristers who had care and conduct of matters concerning the Trewern embankment during the period of August 2005 to January
2007 when the EA and the Powysland Internal Drainage Board (PIDB) started criminal proceedings against the landowner

- a claim in the Queen's Bench Division of the High Court of Justice against Natural Resources Wales (NRW); the successor of the EA for undertaking the work on a publicly maintained flood embankment (known as the Tirymynech embankment) on the opposite side of the River Severn to that of the Trewern embankment contrary to statutory provisions.

The two barristers from Fountains Court, Birmingham, who originally had care and conduct of the matter between August 2005 and January 2007, were dismissed and replaced by two barristers from Grays Inn, London.

\section{Background}

In June 2005, repair and maintenance works were undertaken on the Trewern argae - a $950 \mathrm{~m}$ long earth embankment to provide protection against flooding on Trewern Hall (a grade II*-listed building), access road, farm buildings and agricultural land. The landowner believed that as the works on the Trewern embankment were repair and maintenance, there was no requirement to seek consents from three statutory bodies, namely the EA under the WRA, the PIDB under the LDA and the LPA under the Town and Country Planning Act 1990 (1990) - hereafter referred to as the TCPA.

The PIDB, in particular, zealously sought to have the works on the Trewern embankment undone and pursued the EA and the LPA to take action against the landowner, which resulted in the landowner being served with enforcement notices by the EA and the LPA with the EA and the PIDB starting prosecutions in the Magistrates and Crown Courts. The applications for consent for the works on the Trewern embankment were subsequently made to the EA and the LPA.

The consent for the works on the Trewern embankment was granted under section 109 of the WRA by the minister for environment, 
sustainability and housing of the Welsh Assembly government (WAG) by a letter dated 16 June 2009 (letter reference A-PAE-2401-qA745901/1). To minimise the impact during the high flood-risk season, it was a condition attached to the granting of the consent that works on the Trewern embankment should not be undertaken during 1 October in 1 year to 30 April in the next.

As certain works had already been undertaken on the Trewern embankment prior to the WRA section 110 appeal, an application for retrospective and prospective planning consents was made to the LPA (Powys County Council), on 23 July 2009 (Till, 2009). A request was made to the LPA that the LPA consider the application as soon as possible so as to enable the works on the Trewern embankment to be completed before 1 October 2009 in order to meet the minister's condition. It became clear in early September 2009 that the LPA had no intention of considering the planning application in the near future, consequently it was decided to proceed with the works on the Trewern embankment. The works were completed before 1 October 2009, following which a new submission for a retrospective planning consent was made to the LPA (Till, 2010).

Notwithstanding the successful appeal under section 110 of the WRA and the consent given in accordance with section 109 of the WRA by the minister, the EA and the PIDB submitted objections to the planning applications. The LPA's planning committee considered the application for a retrospective consent at its meeting on 24 August 2010, in which an unconditional planning consent was granted.

Despite the consents granted under section 109 of the WRA and the TCPA, the PIDB continued to seek the undoing of the works on the Trewern embankment by persistently pursuing the landowner to submit an application for a land drainage consent in accordance with the LDA, even though this was not necessary. In the view of the landowner, the PIDB continued to act in a malicious manner.

\section{Statutory requirements}

The principal statutory requirements relied on by the EA, the PIDB and the LPA were as follows.

- Section 109(3) of the WRA states that 'no person shall erect or alter any structure designed to contain or divert floodwaters of any part of a main river except with the consent of and in accordance with plans and sections approved by the Agency'.

- Section 55(1) of the TCPA by which the LPA regarded the works on the Trewern embankment as engineering works for which planning consent was required.

- Section 66 of the Land Drainage Act 1991 (1991), which gave powers to internal drainage boards to make byelaws under which the PIDB sought to have the works on the Trewern embankment undone. Section 66(3)(a) states that such powers 'shall not be exercisable by an internal drainage board in connection with a main river, the banks of such a river or any drainage works in connection with such a river'.

\section{Judicial review of the unconditional planning consent}

A claim in the High Court of Justice (Queen's Bench Division, case CO/12234/2010) issued on 24 November 2010 by Paul Jefferson and Sally Jefferson-Smith of Poole Quay, Welshpool (the area protected from flooding of the River Severn by the Tirymynech embankment), challenged the decision of the LPA to grant a planning permission for retrospective works for the reinstatement and the repair of the Trewern embankment to protect grade II*-listed building, farm buildings, land and access from flooding, together with a borrow pit (planning reference: $\mathrm{P} / 2010 / 08565)$. The action involved the Powys County Council; the LPA, as the defendant; and also Thomas Till and Murray Chapman (the owners) as the interested parties.

In granting permission on 14 March 2011, David Elvin QC, sitting as a deputy High Court judge, ordered that the defendant and any other person served with the claim form who wished to contest the claim or support it on additional grounds had to file and serve detailed grounds for contesting the claim or supporting it on additional grounds and any written evidence within $35 \mathrm{~d}$ after the service of the order granting the permission. The order was served on 30 March 2011.

The claim relied on five grounds

non-consideration of the EA's representations and advice

non-application of Technical Advice Note 15 (WAG, 2010a) and Planning Policy Wales (WAG, 2010b)

- non-application of the unitary development plan strategic policies (Powys County Council, 2010)

- discretion fettered by the WRA appeal

- letter from the agent acting for the applicant of the planning application.

Of the five grounds relied on by the claimant, the judge at the permission stage considered that only grounds 2, 3 and 4 were arguable. The claimant was asked to consider whether it wished to pursue grounds 1 and 5 at the substantive hearing. It was not until the substantive hearing held in Cardiff on 20 July 2011 that the claimant indicated that it wished to reintroduce grounds 1 and 5. As the claimant had not observed rule 54(15) as to the service of notice if an additional point was going to be taken, the judge ordered as follows.

- The costs of the defendant and the interested parties today are awarded against the claimant (associated costs reserved).

- The defendant has $21 \mathrm{~d}$ to file and serve further evidence.

- Each party must file further skeletons $14 \mathrm{~d}$ before the next hearing.

In being aware of the costs awarded against it, the claimant in a letter from its solicitor dated 22 July 2011 offered a 'hands down walk away'. In other words, the claimant would discontinue its action provided that the defendant and the interested parties met 
their own costs. The defendant and the interested parties agreed to this proposal, which brought an end to the matter and provided a certainty to the planning consent for the works on the Trewern embankment. An order to discontinue the action was formally entered into court by the claimant's solicitor in September 2011.

\section{Determination in accordance with section 73 of the LDA}

Both the EA and the PIDB had objected to the application to grant a planning consent for the works on the Trewern embankment despite the decision by the WAG minister to grant consent for the works in accordance with section 109 of the WRA. The PIDB, through its clerk, embarked on an emotive, personalised and vindictive campaign against the owners of Trewern Hall to have the Trewern embankment taken down. The PIDB clerk published a paper entitled 'Illegal flood defence in the floodplain of the River Severn' in the winter edition of the Association of Drainage Authorities (ADA) Gazette (Marwick, 2008). This was immediately following the completion of the 9-d public inquiry to consider the section 110 WRA appeal of the decision by the EA to refuse consent under section 109 of the WRA for works on the Trewern embankment.

When the WAG minister published her decision in a letter dated 16 June 2009 (letter reference A-PAE-24-01-qA745901/1) to uphold the appeal, the clerk of the PIDB published a further paper entitled 'Illegal flood defence in the floodplain of the River Severn - a long and tortuous tale of unfinished business' in the spring edition of the ADA Gazette (Marwick, 2010). In his second paper, the clerk heavily criticised the decision of the WAG minister and made use of very inaccurate hyperbole. He particularly noted that 'it would appear to the Board's Ratepayers affected by this strange and frightening decision that the Assembly Government was more interested in slapping the wrist of the EA for the poor handling of the S109 application than in protecting 30 properties (including 7 farms, 6 of which are dairy farms) from what is in effect a tidal wave of water'.

The PIDB clerk's alleged 'tidal wave of water' from the effect of the Trewern embankment on the flooding regime of the River Severn amounted in reality to an increase in the 1 -in-100 year flood water level by a only few millimetres. The euphemism of the clerk that the EA was 'slapped on the wrist' for its mishandling of the section 109 application is at odds with the damning report of the inspector who conducted the public inquiry to consider the section 110 WRA appeal (Neild, 2008).

The clerk goes on to state that 'the owner must now obtain Land Drainage consent from the Powysland IDB and that The Board will now have to decide if it should stand up to this difficult landowner and take legal action'.

The PIDB's concern was not only the effect the Trewern embankment had on the flooding regime of the River Severn but also the access to maintain Trewern Brook, alongside which the Trewern embankment was constructed. The PIDB's byelaws
(PIDB, 2000) required an $8 \mathrm{~m}$ wide maintenance strip along the edge of the brook for this purpose. The Trewern embankment had originally been constructed during the nineteenth century and it had been determined at the Magistrates Court that the footprint of the newly restored embankment was within the footprint of its original construction. The PIDB, together with the EA, had brought a prosecution in 2006 against the landowner for the restoration of the Trewern embankment in 2005, and in an appeal against the Magistrates' verdict, held in Mold Crown Court in November 2006, the PIDB withdrew its prosecution.

The access to Trewern Brook was available on each side and although the Trewern embankment was within the $8 \mathrm{~m}$ maintenance strip on one side of the brook, the access on the other side remained fully available.

Despite res judicata from the Crown Court proceedings and the obtaining of an unconditional planning consent, the PIDB, as evidenced by the paper published in the spring edition of the $A D A$ Gazette (Marwick, 2010), continued to insist on the landowners submitting an application for consent under the Land Drainage Act 1991 (1991). An ever-increasing number of threatening letters were issued to the landowners by the PIDB. There was no need to obtain an LDA consent for the works as only one authority, the EA, had jurisdiction over the Trewern embankment.

The landowners sought a determination of this issue from the WAG minister in accordance with section 73 of the Land Drainage Act 1991 (1991). Section 73(1) of the Land Drainage Act 1991 (1991) states

'that if any question arises under this Act -

(a) Whether any work is a drainage work in connection with a main river; or

(b) Whether any proposed work will, if constructed, be such a drainage work, the question shall be referred to one of the ministers for decision or, if either of the parties so requires, to arbitration'.

Section 66(1) of the Land Drainage Act 1991 (1991) allows an internal drainage board or a local authority to make such byelaws as they consider necessary for securing the efficient working of the drainage system in their district or area for the purposes defined in section 66(2), namely

(a) Regulating the use and preventing the improper use of any watercourses, banks or works vested in them or under their control or for preserving any such watercourses, banks or works from damage or destruction;

(b) Regulating the opening of sluices and flood gates in connection with any such works as are mentioned in paragraph $(a)$ above;

(c) Preventing the obstruction of any watercourses vested in them or under their control by the discharge into it of any liquid or solid matter or by reason of any such matter being allowed to flow or fall into it; 
(d) Compelling the persons having control of any watercourse vested in the board or local authority or under their control, or of any watercourse flowing into any such watercourse, to cut the vegetable growths in or on the bank of the watercourse and, when cut, to remove them.

Under section 66(3)(a), the Land Drainage Act 1991 (1991) states that the powers conferred by subsections 1 and 2 'shall not be exercisable by an internal drainage board in connection with a main river, the banks of such a river or any drainage works in connection with such a river'.

Section 72(1) defines drainage as including defence against water (including seawater), irrigation, other than spray irrigation and warping.

The approach taken by the Welsh minister in the determination of this matter was to seek representation from not only the landowner (as applicant) but also the PIDB and the EA. The Welsh minister considered the representations made by each party and particularly examined the definition of main river, drainage works and in connection with.

In its representations to the minister, the PIDB suggested that the minister should provide a confirmation that the EA had full jurisdiction over the floodplain of the River Severn, but that the PIDB and the EA had joint jurisdiction over Trewern Brook and the $8 \mathrm{~m}$ maintenance strip on either side of it. The minister responded to this suggestion by declaring that it was clear that the intention of both the Land Drainage Act 1991 (1991) and the Water Resources Act 1991 (1991) (which in section 113(2) contains a provision equivalent to section 73 of the Land Drainage Act 1991 (1991)) is that, in relation to drainage works, the jurisdiction of the EA and the PIDB is to be mutually exclusive (WAG, 2011).

On 4 July 2011, the Welsh minister determined that the works on the Trewern embankment were drainage works in connection with a main river (WAG, 2011). The consequence of this determination is that under sections 14 and 66 of the LDA, the PIDB had no jurisdiction in the matter, and, therefore, its actions were unlawful from the beginning.

On 31 March 2015, the PIDB ceased to exist and its functions were taken over by NRW, the successor to the EA in Wales (HMG, 2015). The area of jurisdiction by the PIDB straddled the border between England and Wales, and the scheme put forward by the NRW and the EA separated out the Welsh and English areas, which would henceforth be administered by the NRW and the EA respectively.

\section{Negligence/breach of duty by two barristers}

In August 2011, the writs issued out of the High Court of Justice claim 1WX 90977 were served against the original two barristers (who had care and conduct of the matters concerning the Trewern embankment between August 2005 and January 2007) from Fountains Court, Birmingham, for the negligence/breach of duty in their conduct of the planning matters associated with the Trewern embankment and the conduct of the defence against the prosecutions brought by the EA and the PIDB.

The heads of claim were as follows

- improperly preparing the application for an injunction to the extent that there was failure to obtain it

- amending a certificate of lawful existing use and development application to the LPA to the extent that the amendment by the barristers rendered the application to be ineffective: the LPA refused the application and the planning inspector at the appeal indicated that the wording of the application was flawed

not recognising that the PIDB did not have any jurisdiction in the matter

- not recognising that the realignment of a very short length of the flood protection embankment (about $5 \%$ of its length) was fatal to the defence against the appeal in the Crown Court

- failure to advise that an application for the work should have been made in accordance with section 109 of the WRA.

Bar Mutual, who provided professional indemnity for the two barristers, acted on their behalf in the proceedings. The matter was concluded by way of a mediation held on 25 March 2014 at The Queens Hotel, Chester, with the claim against one of the barristers being dismissed and an agreement reached which was satisfactory to the claimant.

\section{Claim against NRW}

On 16 September 2010, a claim for damages was submitted by the owners of Trewern Hall to the EA for works it had undertaken on the Tirymynech embankment (a public flood defence work to protect people, livestock and properties in an area known as Poole Quay) which it had started on 29 May 2007. It had the effect of increasing the risk to Trewern Hall from the floodwaters of the River Severn. It became clear from enquiries made under the Freedom of Information Act 2000 (2000) and the meetings with the EA that it had failed to observe the following statutory provisions.

- Regulations 3-(1) and 5 of the Environmental Impact Assessment (Land Drainage Improvement Works) Regulations 1999 (HMG, 1999): regulation 3-(1) states that a 'drainage body shall not carry out any improvement works unless they have complied with the requirements of these Regulations in relation to those improvement works'. As the EA did not undertake an environmental impact assessment for the works, it was, nevertheless, required under regulation 5 to advertise the works, which it failed to do.

- The amendment to regulation 5 of the Environmental Impact Assessment (Land Drainage Improvement Works) (HMG, 2005) required the EA to consult with CADW 
(the Welsh equivalent of English Heritage), which the EA failed to do.

- There is also a requirement by section $61 \mathrm{~A}-1(\mathrm{~b})$ of the Land Drainage Act 1994 (1994) for the EA to have regard to the desirability to protecting and conserving buildings, sites and objects of archaeological, architectural or historic interest, which the EA also failed to do.

As the EA dismissed the claim, it was in 2013 entered into the High Court of Justice Queen's Bench Division case no. HQ13X02061 and also the Upper Tribunal (Lands Chamber) Case LCA/36/2013. In the mean time, the functions of the EA in Wales were undertaken by the NRW.

The claim for the damages against NRW was under six heads as follows

- depreciation in the value of Trewern Hall resulting from increased risk of flooding

- professional fees incurred in obtaining planning permission for the works on the Trewern embankment

- cost of works to repair the Trewern embankment

v professional fees incurred in the design and the engineering assessment of the Trewern embankment

- commuted maintenance costs of maintenance of the Trewern embankment

- professional fees incurred in obtaining section 73 LDA determination.

On 23 February 2015, a mediation was held in Grays Inn, London, at which a settlement was agreed whereby NRW undertook to

(a) pay $£ 115000$ to the claimant by 10 March 2015

(b) provide a letter to be placed with the Land Registry for Trewern Hall property relating to the flood protection provided by the Trewern embankment

(c) use its best endeavours to acknowledge the benefit of the Trewern embankment private flood defence on the EA's national flood risk mapping systems.

In meeting the requirements of item $(b)$ of the agreement made at the mediation, the NRA's head of operations mid-Wales provided a letter dated 11 March 2015 to the owners of Trewern Hall, which stated the following.

\footnotetext{
If an enquiry is directed to NRW as to flood defence applicable to Trewern Hall, Welshpool ('the Property') it will confirm that a flood defence (known as Trewern embankment) was erected in accordance with the Planning Permission dated 24 August 2010 and, insofar as it has been maintained in good condition in accordance with the approved plans, then it was designed to defend to a $1 \%$ flood level.
}

\section{Conclusions}

It is acknowledged that the issues relating to flooding are very emotive, but it was never foreseen that there would be further challenges by the EA and the PIDB which involved further litigation subsequent to the granting of consent in accordance with section 109 of the WRA for works on the Trewern embankment.

The EA (now known as NRW) and the PIDB were both shown to have acted unlawfully, but there is no means of bringing such statutory bodies to account for acting unreasonably and unlawfully without resorting to the legal system.

It required a great deal of tenacity and strength of purpose by private individuals to bring the matter to a conclusion. It was a formidable challenge to take on statutory bodies which have unlimited funds to fight legal challenges.

It is unfair that statutory bodies can act negligently without being liable for their actions, unlike the private sector.

\section{Acknowledgements}

The participants in the litigation included solicitors Emrys Jones \& Co., Welshpool; DTM Legal, Chester; barristers Steven Gasztowicz QC and Jonathan Clay; Cornerstone Barristers, Grays Inn; and planning consultant Ian Pryce Property Services, Montgomery.

\section{REFERENCES}

Chapman ML (2011) First ever appeal under section 110 of the UK Water Resources Act 1991. Proceedings of the Institution of Civil Engineers - Management Procurement and Law 164(4): 203-208, http://dx.doi.org/10.1680/mpal.2011.164.4.203.

Freedom of Information Act 2000 (2000) Elizabeth II. Chapter 36. Her Majesty's Stationery Office, London, UK.

HMG (Her Majesty's Government) (1999) Land Drainage. The Environmental Impact Assessment (Land Drainage Improvement Works) Regulations. The Stationery Office, London, UK, Statutory Instrument 1999 No. 1783.

HMG (2005) Land Drainage, England and Wales. Environmental Impact Assessment (Land Drainage Improvement Works) (Amendment) Regulations 2005. The Stationery Office, London, UK, Statutory Instrument 2005 No. 1399.

HMG (2015) Land Drainage, England and Wales. The Powysland Internal Drainage District (Abolition) Order 2015. The Stationery Office, London, UK, Statutory Instrument 2015 No. 923.

Land Drainage Act 1991 (1991) Elizabeth II. Chapter 59. Her Majesty's Stationery Office, London, UK.

Land Drainage Act 1994 (1994) Elizabeth II. Chapter 25. Her Majesty's Stationery Office, London, UK.

Marwick J (2008) Illegal flood defence in the floodplain of the River Severn. ADA Gazette 2008(Winter): 12-13.

Marwick J (2010) Illegal flood defence in the floodplain of the River Severn - a long and tortuous tale of unfinished business. ADA Gazette 2010(Spring): 18-19.

Neild C (2008) Water Resources Act 1991 and Town and Country Planning Act 1990: Environment Agency \& Powys County Council: Appeals by Mr Thomas Till. Land at Trewern Hall, Trewern, Welshpool, Powys. The Planning Inspectorate, 
Cardiff, UK, report APP/T6850/P/08/515054 and APP/T6850 X/07/20608884 \& 2060918.

PIDB (Powysland Internal Drainage Board) (2000) Powysland Internal Drainage Board Byelaws. Powysland Internal Drainage Board, Llandrinio, UK. See http://www.powyslandidb.org.uk/ downloadfile.php?id=6 (accessed 23/02/2016).

Powys County Council (2010) Unitary Development Plan Strategic Policies. Powys County Council, Llandrindod Wells, UK.

Till T (2009) Part Section 70 for Prospective Works and Part Section 73 A (T.C.P.A. 1990) Application for Retrospective Works for the Reinstatement and Repair to Trewern Argae to Protect Grade II* Listed Building, Farm Buildings, and Access from flooding together with a Borrow Pit. Powys County Council, Llandrindod Wells, UK, planning application $\mathrm{P} / 2009 / 0798$
Till T (2010) Section 73 A (T.C.P.A. 1990) Application for Retrospective Works for the Reinstatement and Repair to Trewern Argae to Protect Grade II* Listed Building, Farm Buildings, and Access from Flooding together with a Borrow Pit. Powys County Council, Llandrindod Wells, UK, planning application P/2010/0565.

Town and Country Planning Act 1990 (1990) Elizabeth II. Chapter 8. Her Majesty's Stationery Office, London, UK. WAG (Welsh Assembly Government) (2010a) Technical Advice Note 15. Development and Flooding Risk, 3rd edn. Welsh Assembly Government, Cardiff, Wales.

WAG (2010b) Planning Policy Wales, 2nd edn. Welsh Assembly Government, Cardiff, UK.

Water Resources Act 1991 (1991) Elizabeth II. Chapter 57. Her Majesty's Stationery Office, London, UK.

\section{WHAT DO YOU THINK?}

To discuss this paper, please submit up to 500 words to the editor at journals@ice.org.uk. Your contribution will be forwarded to the author(s) for a reply and, if considered appropriate by the editorial panel, will be published as a discussion in a future issue of the journal.

Proceedings journals rely entirely on contributions sent in by civil engineering professionals, academics and students. Papers should be 2000-5000 words long (briefing papers should be 1000-2000 words long), with adequate illustrations and references. You can submit your paper online via www.icevirtuallibrary.com/content/journals, where you will also find detailed author guidelines. 